\title{
IDENTIFYING THE KEY FACTORS AND PROPOSING A ROADMAP FOR SUCCESSFUL LEAN TRANSFORMATION IN VIETNAMESE MANUFACTURING FIRMS
}

\author{
Bui Nguyen Hung ${ }^{1}$, Le Phuoc Luong ${ }^{2}$, Nguyen Thi Duc Nguyen ${ }^{3}$ \\ ${ }^{1,2} 3$ Ho Chi Minh City University of Technology, VNU (Vietnam) \\ Email: lpluong@hcmut.edu.vn
}

(Received: 05/09/2015; Revised: 05/11/2015; Accepted: 07/12/2015)

\begin{abstract}
This study is conducted to identify the key factors and propose a roadmap for successful lean transformation in Vietnamese manufacturing firms. Eight managers of two companies having successful lean performances and two lean experts from university and consulting company are invited to participate in semi-structured interviews to verify key factors of a successful lean transformation as well as to promote a lean roadmap with tools used for lean transformation in the context of Vietnam. The research results show that 10 key factors promoting a successful lean transformation are Role of management, Involvement and Commitment to change, Balanced scorecard implementation, Corporate vision and values, Corporate culture of change, Persuasive situation for change, Change projects, KPI application, Lean consultants, and Stakeholder communication. The respondents also adopt a roadmap for a successful lean transformation in Vietnamese companies including 3 phases (preparation, implementation, maintenance and improvement) in which 5S, Visual Control, and Work Standardization are the three most remarkable tools for lean transformation.
\end{abstract}

Keywords: Success factors, Lean transformation, Lean roadmap, Lean tools, Vietnamese companies.

\section{Introduction}

"95\% of the Lean implementation efforts have failed, while only $5 \%$ have been successful" is a conclusion of a chairman of American Lean Horizons Consulting Organization (Ransom, 2007). In additional, a strategic program manager of Intel Corp reveals that about $60 \%$ of Lean transformation efforts fail (Wooley, 2008). In Vietnam, Lean has been applied to more and more companies and it is not still a really new concept. However, as to an expert of Vietnam Lean Symposium, the first International Conference of Lean implementation in all industries of Vietnam, around $75 \%$ Vietnamese companies know and apply Lean for their operations; yet, only $2 \%$ of these companies achieve the successes (FBNC Vietnam, 2013).

The causes of Vietnamese companies' failures in applying Lean are not mentioned officially in previous studies. However, according to experts and managers of the companies (among 2\% of Vietnamese organizations achieving lean successes), there are many obstacles that Vietnamese firms must get over to reach the successes in lean transformation. The most critical issue is to create a strong corporate Lean culture, in which the commitments of top managers and the participation of all employees are two 
factors making the success of Lean implementation for Vietnamese organizations (Nguyen \& Bui, 2010).

It is, therefore, believed that Vietnamese companies must consider factors of success for their transformation. In the global context, there have been many studies focusing on exploring success factors of lean transformation such as: Culture, Leadership, People capability, Execution, Continuous improvement, Organization (Simoes, 2008; Reiders, 2010; Alsbridge, 2013). The authors mention that companies should invest themselves in these six groups of factors to get the successes in Lean transformation. Besides, many authors also propose different roadmaps for successful lean transformation. Among them, some authors suggest a lean roadmap with three phases: preparation, implementation, maintenance and improvement (Liker, 2004; Simoes, 2008). The other authors propose other different roadmaps for lean transformation such as: A proposed dynamic roadmap to leanness (Anvari et al., 2011), Lean six sigma roadmap (Vinodh, Gautham \& Ramiya, 2011) and so on. In each phase, the authors suggest useful methods and tools that are remarkably significant to lean successes such as: 5S, Kanban, Kaizen, TPM, Poka-yoke, Andon ... (Liker, 2004; Simoes, 2008; Anvari et al., 2011; Vinodh, Gautham \& Ramiya, 2011). However, in the context of Vietnam, there is a lack of study which officially focuses on identifying key success factors for lean transformation as well as promotes a roadmap for a successful lean transformation. Therefore, this study is conducted to verify key factors of a successful lean transformation based on relevant studies of previous authors all over the world to adapt to Vietnamese manufacturing companies. The study also promotes a lean roadmap with tools and methods used for lean transformation to help Vietnamese manufacturing companies to reach successes in lean transformation.

\section{Literature review}

\section{Success factors for lean transformation}

Based on many studies, 32 success factors for Lean transformation are extracted into six groups: Organization, Leadership, People capability, Execution, Continuous improvement, and Culture (Alsbridge, 2013). In terms of organization, the componential factors that contribute to a successful lean transformation are: business model, governance type, corporate resources and competency, size of capital ad assets, technological standard, human resource, quality management system, life span and industry experience, role of labor union and other communities (Alsbridge, 2013; Reiders, 2010).

Leadership is also an important factor for lean successes. The role of top management (CEO, Chairman, Production director, and Functional directors) is highly evaluated as a key factor in directing and motivating the corporate staff to achieve the successes in operations (Simoes, 2008; Reiders, 2010). Besides, leadership style (such as being arbitrary, autocracy, democratic, or assertive) can have strong influences on the success of lean transformation (Perrett, 2011; Rose et al., 2010). The involvement and commitment to change of top management are also critical to get the success in lean application (Alsbridge, 2013; Rose et al., 2010). Finally, decision making manner (centralized-based, decentralized - based, or procedural-based) is the other important aspect of leadership that drives an organization to lean successes (Reiders, 2010).

Many authors support the idea that people capability cannot be separate from key success factors of lean transformation (Simoes, 2008; Reiders, 2010; Alsbridge, 2013). In this term, the authors mention about available relevant competences of human resources for transformation such as industry knowledge, specialized skills, management skills, working experience, system of policies, 
procedures, and working standards. Besides, corporate capabilities (developing new competences relevant to lean transformation, planning and implementing the training programs on new working and management methods, career planning and employee development) are proposed to be important factors of people capability that contribute to lean successes (Simoes, 2008; Reiders, 2010).

In terms of execution, the lean transformation is initiated by a change project to new management model such as lean project, 5S, or TPM (Alsbridge, 2013). Execution is also shown through a proper and effective application of project management, for example defining proper scope of lean implementation, estimating and preventing risks of resource scatter caused by responding to competition and economy crisis. Other aspects of execution such as key success factors of lean transformation are added: project team competency, resource reallocation, communication management, stakeholder management, legal compliance, optional solutions and assistance of external experts or lean consultants (Simoes, 2008; Reiders, 2010; Rose et al., 2010).

The other group of success factors in lean transformation is continuous improvement. Some activities that a company should do to be successful in lean transformation are: application of balanced scorecard, and application of performance management (Reiders, 2010). A company achieving a lean success must have adequate budgets for and deployment of policies of performance appraisal as well as employee compensation (Alsbridge, 2013). Besides, companies should have a stakeholder communication to improve themselves continuously. Besides, supply chain style (Make To Stock/ Make To Orders) and ability to expand lean to supply chain is necessarily important to an organizational continuous improvement (Simoes, 2008).

The final group of success factors for lean transformation is Culture. Companies should have a culture in which corporate vision, values, code of conducts, standards are stated clearly and comprehensively (Simoes, 2008). A strong culture that facilitates the lean success also includes characteristics such as: being reasonable and persuasive situation for change, promoting the abilities and readiness of individuals and the whole organization in change implementation, having agreement on strategies and plans to respond to difficulties and obstacles to prevent initiatives and plans from misleading, possessing sustainment of ethics, code of conducts under the impacts of temporary benefits, and having policies, rituals that facilitate continuous improvement culture (Reiders, 2010; Anvari et al., 2011).

\section{Lean roadmap with tools and methods used for lean transformation}

Based on the previous studies, the following table is presented to synthesize lean roadmaps suggested by different authors. In each lean roadmap, tools and methods are also proposed to achieve the success for lean transformation.

Table 1. Overview of lean roadmaps proposed by recent studies

\begin{tabular}{|c|c|c|c|}
\hline Authors & Brief description & Phases of lean roadmap & Lean tools/methods \\
\hline Simoes (2008) & $\begin{array}{l}\text { A proposed roadmap for } \\
\text { lean transformation }\end{array}$ & $\begin{array}{l}\text { Preparation } \\
\text { Implementation } \\
\text { Maintenance } \\
\text { improvement }\end{array}$ & $\begin{array}{l}\text { 5S, Kanban, } \\
\text { Poka-yoke, leveled } \\
\text { production, } \\
\text { controls, } \\
\text { Standardization, } \\
\text { TPM, Andork } \\
\text { TPaizen }\end{array}$ \\
\hline
\end{tabular}




\begin{tabular}{|c|c|c|c|}
\hline Authors & Brief description & Phases of lean roadmap & Lean tools/methods \\
\hline $\begin{array}{l}\text { Van-Aken et al. } \\
(2010)\end{array}$ & $\begin{array}{l}\text { A roadmap for designing, } \\
\text { managing and supporting } \\
\text { continuous improvement } \\
\text { programs }\end{array}$ & $\begin{array}{l}\text { Plan } \rightarrow \text { Implement } \\
\rightarrow \text { Sustain } \rightarrow \text { Support }\end{array}$ & $\begin{array}{l}\text { Kaizen, Work } \\
\text { Standardization }\end{array}$ \\
\hline $\begin{array}{l}\text { Anvari et al. } \\
(2011)\end{array}$ & $\begin{array}{l}\text { A proposed dynamic } \\
\text { roadmap to leanness }\end{array}$ & $\begin{array}{l}\text { Initial investigation } \rightarrow \\
\text { Preparation } \rightarrow \text { Pilot } \\
\text { project } \rightarrow \text { Expand } \rightarrow \\
\text { Pursue of perfection }\end{array}$ & $\begin{array}{l}\text { Kaizen, } 5 \text { whys, } \\
\text { Work Standardization }\end{array}$ \\
\hline $\begin{array}{l}\text { Vinodh, } \\
\text { Gautham \& \& } \\
\text { Ramiya }(2011)\end{array}$ & $\begin{array}{l}\text { A lean sigma roadmap for } \\
\text { automotive } \\
\text { manufacturers }\end{array}$ & $\begin{array}{l}\text { Define } \rightarrow \text { Measure } \rightarrow \\
\text { Analyze } \rightarrow \text { Improve } \rightarrow \\
\text { Control }\end{array}$ & $\begin{array}{l}\text { VSM, Cause-Effect } \\
\text { diagram, } \quad \text { Quick- } \\
\text { changeover, Kaizen }\end{array}$ \\
\hline $\begin{array}{l}\text { Bortolotti \& } \\
\text { Romano (2012) }\end{array}$ & $\begin{array}{l}\text { A lean management } \\
\text { roadmap }\end{array}$ & $\begin{array}{l}\text { Lean first } \rightarrow \text { Then } \\
\text { automate }\end{array}$ & $\begin{array}{l}\text { VSM, Kaizen, Work } \\
\text { Standardization }\end{array}$ \\
\hline $\begin{array}{l}\text { Suhartini, } \\
\text { Razauddin \& } \quad \& \\
\text { Nizam (2012) }\end{array}$ & $\begin{array}{l}\text { A proposed roadmap of } \\
\text { Set-Parts } \\
\text { implementation } \\
\text { assembly line }\end{array}$ & $\mid \begin{array}{ll}\text { Visual management } & \rightarrow \\
\text { Standardized process } & \rightarrow \\
\text { Just in Time } & \rightarrow \\
\text { Continuous improvement }\end{array}$ & $\begin{array}{lr}\text { Visual } & \text { control, } \\
\text { Jidoka, } & \text { Kaizen, } \\
\text { Kanban, } 5 & \text { whys, } \\
\text { Cause-Effect } & \\
\text { diagram, Poka-yoke, } \\
\text { Work Standardization }\end{array}$ \\
\hline $\begin{array}{l}\text { Karim \& Arif- } \\
\text { Uz-Zaman } \\
(2013)\end{array}$ & $\begin{array}{l}\text { A lean implementation } \\
\text { roadmap for } \\
\text { manufacturing } \\
\text { organizations }\end{array}$ & $\begin{array}{l}\text { Value proposition } \rightarrow \\
\text { Value stream } \rightarrow \text { Flow } \rightarrow \\
\text { Pull } \rightarrow \text { Perfection }\end{array}$ & $\begin{array}{l}\text { VSM, Kaizen, Cross } \\
\text { functional workers, } \\
\text { Work Standardization }\end{array}$ \\
\hline $\begin{array}{ll}\text { Jagoda, Lonseth } \\
\& & \text { Lonseth } \\
(2013) & \end{array}$ & $\begin{array}{lr}\text { A } & \text { continuous } \\
\text { improvement roadmap for } \\
\text { productivity improvement }\end{array}$ & $\begin{array}{ll}\text { Focus } \rightarrow \text { Measure } & \rightarrow \\
\text { Communicate } & \rightarrow \\
\text { Innovate and improve } & \rightarrow \\
\text { Evaluate } & \end{array}$ & $\begin{array}{l}5 \mathrm{~S}, \quad \text { Quick- } \\
\text { changeover, Problem- } \\
\text { solving techniques, } \\
\text { TPM }\end{array}$ \\
\hline
\end{tabular}

As shown in Table 1 , recent studies utilize different approaches for successful lean transformation. These roadmaps are designed for lean transformation in different countries such as USA, India, Malaysia... In each country, there should be modifications for suitable adaptions to the contexts. In this study, for the context of Vietnamese manufacturing companies, a roadmap is proposed based on the recent studies such as: Simoes (2008), Van-Aken et al. (2010), Anvari et al. (2011), Vinodh, Gautham \& Ramiya (2011), Bortolotti \& Romano (2012), Suhartini, Razauddin \& Nizam (2012), Karim \& Arif-Uz-Zaman (2013), and Jagoda, Lonseth \& Lonseth (2013). This proposed roadmap is utilized to ask the experts and managers (of Vietnamese successful lean companies) to modify phases and tools in the roadmap and create an appropriate lean roadmap for Vietnamese firms.

\section{Research methodology}

In this study, the respondents are chosen based on the convenient sampling with 8 managers (Chairman, CEO, Vice CEO, Middle managers of functional departments, and supervisors of all shop-floors) from 2 manufacturing companies, 1 lean professor from a university, and 1 lean expert from a consultant company. They are invited to assess and verify the key factors and a roadmap for successful lean transformation in 
the context of Vietnam. The two chosen companies have applied Lean philosophy for more than two years and achieve certain lean successes. These companies have already used multiple Lean tools such as 5S, Kanban, Jidoka, Poka-yoke, leveled production, visual controls, Work Standardization, TPM, Andon, Kaizen, and so on for their operations. The managers and experts chosen in this study are ones who directly manage or consult the Lean action plans so that they have sufficient experiences and abilities to verify the key factors and a roadmap for successful lean transformation which are based on literature reviews. The information of these respondents is presented in the Table 2.

Table 2. Information of chosen managers and experts for the study

\begin{tabular}{|c|c|c|c|c|}
\hline Respondent & Job title & Product & $\begin{array}{c}\text { Lean } \\
\text { experience }\end{array}$ & Lean performance \\
\hline M1 & $\begin{array}{l}\text { Chairman of } \\
\text { Company A }\end{array}$ & \multirow[t]{4}{*}{$\begin{array}{c}\text { Carton } \\
\text { Packaging }\end{array}$} & 5 years & \multirow{4}{*}{$\begin{array}{l}\text { In recent } 6 \text { months: Inventories } \\
\text { decreased } 30 \% \text {, Change-over time } \\
\text { decreased } 40 \% \text {, Defects decreased } \\
50 \% \text {, Labor turnover decreased } \\
60 \% \text {. }\end{array}$} \\
\hline M2 & CEO of Company A & & 5 years & \\
\hline M3 & $\begin{array}{l}\text { Vice CEO of } \\
\text { Company A }\end{array}$ & & 5 years & \\
\hline M4 & $\begin{array}{l}\text { Production Manager } \\
\text { of Company A }\end{array}$ & & 5 years & \\
\hline M5 & CEO of Company B & \multirow{4}{*}{$\begin{array}{l}\text { Printing } \\
\text { products }\end{array}$} & 5 years & \multirow{4}{*}{$\begin{array}{l}\text { In recent } 6 \text { months: Inventories } \\
\text { decreased } 20 \% \text {, Change-over time } \\
\text { decreased } 50 \% \text {, Defects decreased } \\
30 \% \text {, Labor turnover decreased } \\
50 \% \text {. }\end{array}$} \\
\hline M6 & $\begin{array}{l}\text { Production Manager } \\
\text { of Company B }\end{array}$ & & 5 years & \\
\hline M7 & $\begin{array}{l}\text { Line Supervisor of } \\
\text { Company B }\end{array}$ & & 4 years & \\
\hline M8 & $\begin{array}{l}\text { Line Supervisor of } \\
\text { Company B }\end{array}$ & & 2 years & \\
\hline E1 & \multicolumn{2}{|l|}{ Professor } & 15 years & $\begin{array}{l}\text { Teaching and consulting in Lean } \\
\text { manufacturing for foreign and } \\
\text { domestic companies for more than } \\
15 \text { years }\end{array}$ \\
\hline E2 & \multicolumn{2}{|c|}{$\begin{array}{l}\text { Lean Expert of Consultant } \\
\text { Company }\end{array}$} & 7 years & $\begin{array}{l}\text { Consulting in Lean philosophy for } \\
\text { foreign and domestic companies for } \\
\text { more than } 7 \text { years }\end{array}$ \\
\hline
\end{tabular}

These managers and experts are asked to assess the importance of 32 factors contributing to the lean successes extracted from the previous studies: Alsbridge (2013), Reiders (2010), Simoes (2008), Rose et al. (2010), and Anvari et al. (2011). Each factor is scored from 1 to 5 . Level 1 presents the lowest importance and level 5 presents the highest importance. Then, these respondents are invited for semi-structured interviews. Based on the scores marked by each respondent, this person is interviewed deeply about the scores. In some cases, the scores do not match his explanations so that the respondent is asked to correct the scores. These respondents are also asked for their ideas about the lean roadmap which is proposed based on recent studies in Table 1. 
In this session, a focus group is conducted to verify the steps and phases of the proposed lean roadmap. The group of respondents is also asked to verify the tools and methods used for each step in the lean roadmap.

Together with the qualitative data, quantitative data are used to analyze and verify the lean success factors that can be used for manufacturing companies in Vietnam. The importance of each factor is identified by the frequencies of scores marked by all respondents. The lean roadmap and recommendations for Vietnamese companies are delivered based on the ideas of all respondents.

\section{Research results}

Success factors for lean transformation

Among 32 proposed success factors for lean transformation, the managers and experts have the highest assessments for 10 factors that are shown in Table 3. The respondents suggest that these 10 factors should be considered firstly for a successful lean transformation in Vietnamese manufacturing companies.

As a result, role of top management is adopted as the most important factor for a lean success by all the respondents (10/10 respondents score this factor with the highest level of importance). At a second place, involvement and commitment to change is the factor that 9/10 respondents give the highest score. Managers M4 and M6 claim that a lean implementation would fail if the top management did not pay attention and give the commitment to follow it. Experts E1 and E2 comment that a company could not conduct a lean project successfully if the top managers did not recognize that a change was necessary for their strategic and operational plans.

Table 3. Top 10 factors having strongest influence on a successful lean transformation

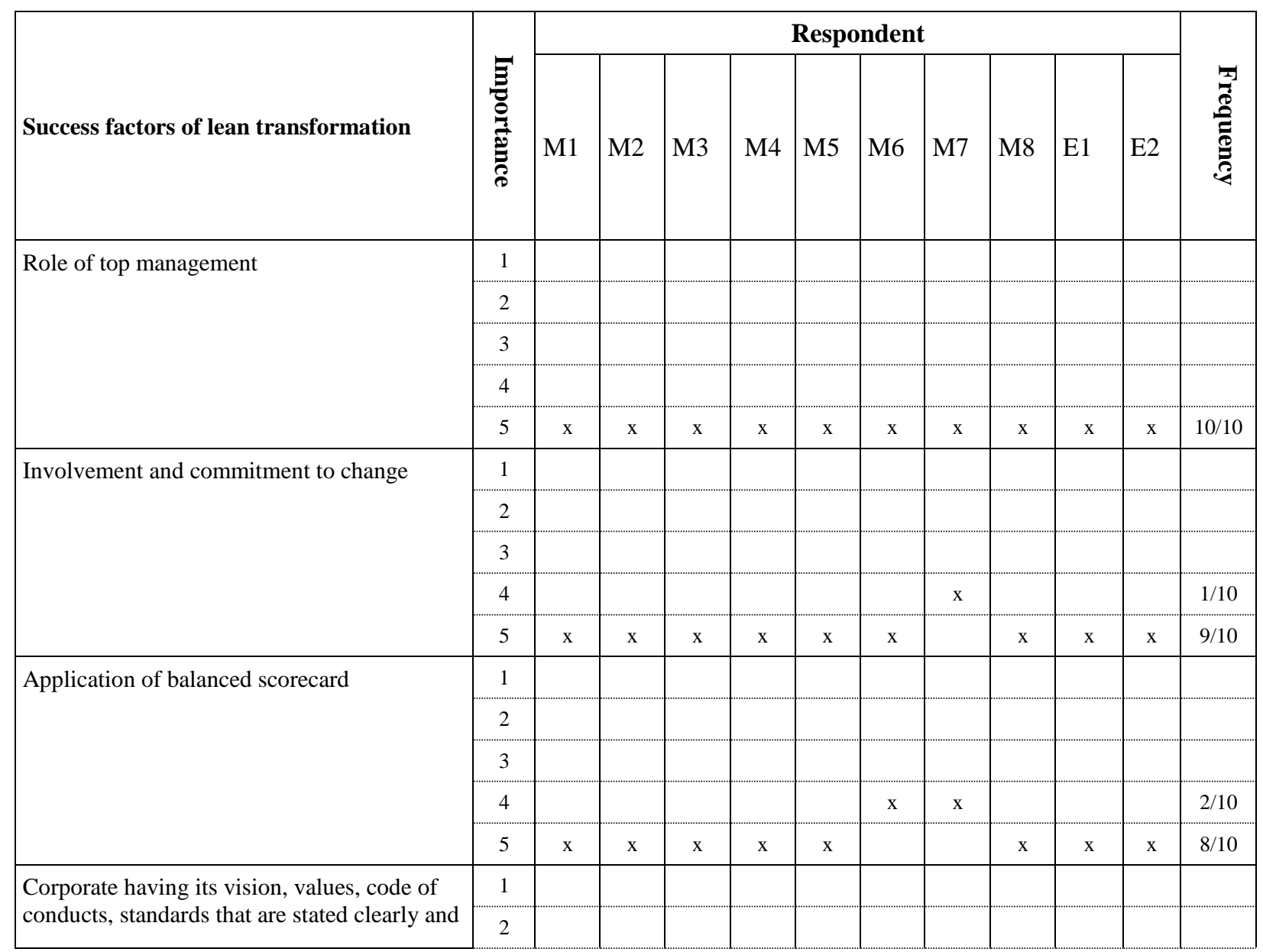




\begin{tabular}{|c|c|c|c|c|c|c|c|c|c|c|c|c|}
\hline \multirow[t]{3}{*}{ comprehensively } & 3 & & & & & & & & & & & \\
\hline & 4 & & & & & & $\mathrm{x}$ & $\mathrm{x}$ & & & & $2 / 10$ \\
\hline & 5 & $\mathrm{x}$ & $\mathrm{x}$ & $\mathrm{x}$ & $\mathrm{x}$ & $\mathrm{x}$ & & & $\mathrm{x}$ & $\mathrm{x}$ & $\mathrm{x}$ & $8 / 10$ \\
\hline \multirow{5}{*}{$\begin{array}{l}\text { Corporate having culture that facilitates the } \\
\text { abilities and readiness of individuals and the } \\
\text { whole organization in change implementation }\end{array}$} & 1 & & & & & & & & & & & \\
\hline & 2 & & & & & & & & & & & \\
\hline & 3 & & & & & & & & & & & \\
\hline & 4 & & & & & & $\mathrm{x}$ & $\mathrm{x}$ & $\mathrm{x}$ & & & $3 / 10$ \\
\hline & 5 & $\mathrm{x}$ & $x$ & $\mathrm{x}$ & $\mathrm{x}$ & $\mathrm{x}$ & & & & $\mathrm{x}$ & $\mathrm{x}$ & $7 / 10$ \\
\hline \multirow{5}{*}{$\begin{array}{l}\text { Corporate having reasonable and persuasive } \\
\text { situation for change }\end{array}$} & 1 & & & & & & & & & & & \\
\hline & 2 & & & & & & & & & & & \\
\hline & 3 & & & & & & & $\mathrm{x}$ & & & & $1 / 10$ \\
\hline & 4 & & & & & & $\mathrm{x}$ & & $\mathrm{x}$ & & & $2 / 10$ \\
\hline & 5 & $\mathrm{x}$ & $\mathrm{x}$ & $\mathrm{x}$ & $\mathrm{x}$ & $\mathrm{x}$ & & & & $\mathrm{x}$ & $\mathrm{x}$ & $7 / 10$ \\
\hline \multirow{5}{*}{$\begin{array}{l}\text { Transformation is initiated by a change } \\
\text { project to new management model (such as } \\
\text { lean project, } 5 \mathrm{~S} . . \text { ) }\end{array}$} & 1 & & & & & & & & & & & \\
\hline & 2 & & & & & & & & & & & \\
\hline & 3 & & & & & & & $\mathrm{x}$ & & & & $1 / 10$ \\
\hline & 4 & & & & $\mathrm{x}$ & & & & $\mathrm{x}$ & & & $2 / 10$ \\
\hline & 5 & $\mathrm{x}$ & $\mathrm{x}$ & $\mathrm{x}$ & & $\mathrm{x}$ & $\mathrm{x}$ & & & $\mathrm{x}$ & $\mathrm{x}$ & $7 / 10$ \\
\hline \multirow{5}{*}{$\begin{array}{l}\text { Application of performance management } \\
\text { (such as KPI...) }\end{array}$} & 1 & & & & & & & & & & & \\
\hline & 2 & & & & & & & & & & & \\
\hline & 3 & & & & $\mathrm{x}$ & & & & & & & $1 / 10$ \\
\hline & 4 & & & & & & & $\mathrm{x}$ & $\mathrm{x}$ & & & $2 / 10$ \\
\hline & 5 & $\mathrm{x}$ & $\mathrm{x}$ & $\mathrm{x}$ & & $\mathrm{x}$ & $\mathrm{x}$ & & & $\mathrm{x}$ & $\mathrm{x}$ & $7 / 10$ \\
\hline \multirow{5}{*}{$\begin{array}{l}\text { Assistance of external experts or lean } \\
\text { consultants }\end{array}$} & 1 & & & & & & & & & & & \\
\hline & 2 & & & & & & & & & & & \\
\hline & 3 & & & & & & & $\mathrm{x}$ & & & & $1 / 10$ \\
\hline & 4 & & & & $\mathrm{x}$ & & & & $\mathrm{x}$ & & & $2 / 10$ \\
\hline & 5 & $\mathrm{x}$ & $\mathrm{x}$ & $\mathrm{x}$ & & $\mathrm{x}$ & $\mathrm{x}$ & & & $\mathrm{x}$ & $\mathrm{x}$ & $7 / 10$ \\
\hline \multirow[t]{5}{*}{ Stakeholder communication } & 1 & & & & & & & & & & & \\
\hline & 2 & & & & & & & & & & & \\
\hline & 3 & & & & & & & $\mathrm{x}$ & & & & $1 / 10$ \\
\hline & 4 & & & & $\mathrm{x}$ & & & & $\mathrm{x}$ & & & $2 / 10$ \\
\hline & 5 & $\mathrm{x}$ & $\mathrm{x}$ & $\mathrm{x}$ & & $\mathrm{x}$ & $\mathrm{x}$ & & & $\mathrm{x}$ & $\mathrm{x}$ & $7 / 10$ \\
\hline
\end{tabular}

At the third places, "Application of balanced scorecard" and "Corporate having its vision, values, code of conducts, standards that are stated clearly and comprehensively" are the two factors getting the highest score from 8/10 respondents. Managers M3 and M5, with more than 3 years applying balanced scorecard, totally agree that balanced scorecard is really helpful to align business activities to the vision and strategy of the organization, improve internal and external communications, and monitor organization performance in accordance to strategic goals. Thus, balanced scorecard application should be included in a list of the most important factor for a successful lean implementation. Besides, manager M2 insists that having corporate vision, values, code of conducts, standards stated clearly and comprehensively is a basic and compulsory element for lean 
implementation. The vision, values, code of conducts, and standards must be focused on customers and stimulate the staff to improve their activities continuously.

To be successful in lean transformation, building a corporate culture for change is very important. Thus, the three factors of this group ("Corporate having culture that facilitates the abilities and readiness of individuals and the whole organization in change implementation", "Corporate having reasonable and persuasive situation for change" and "Transformation is initiated by a change project to new management model") are given the highest score from $7 / 10$ respondents. As a chairman of company $\mathrm{A}$, respondent M2 state that all the shareholders of the company expect that the top management has an ability of creating a corporate culture which encourages and motivates all the employees and the whole company to be ready to changes. Experts E1 and E2 share the stories of some Vietnamese manufacturing companies achieving the lean successes since they always have action plans in which resources are prepared carefully and allocated appropriately to have a reasonable and persuasive situation for change. In additional, the production manager M6 claims that a successful lean transformation must be initiated by an official change project (such as a lean project with official lean team) to attract the attentions of top management and all employees in the company.

The three others in top 10 success factors are "Application of Performance Management (such as KPI...)", "Assistance of external experts or lean consultants", and "Stakeholder communication". These factors are also get the highest scores from 7/10 respondents. All top managers of the two company and experts (M1, M2, M3, M5, E1, E2) believe that performance management such as KPI plays a role as a standard for the lean assessment and control. It is impossible to conduct a lean transformation successful without assessment criteria. They also support the idea that the assistance of external experts or lean consultants is really necessary for a lean project. External experts can provide the corporate with deep knowledge of lean principles as well as propose the practicing lean tools and methods intelligently and continuously depending on real context of the enterprise. Finally, the respondents believe that the communication with stakeholders such as customers, suppliers and shareholders is a smart approach to determine which aspects should be improved to meet their demands and requests. It also motivates the whole company to identify the wastes that must be removed to strengthen the competitive competence of the company in accordance with the stakeholders' requests.

Lean roadmap with tools and methods used for lean transformation

All 10 respondents adopt a roadmap including 24 steps divided into 3 phases for lean transformation (shown in Table 4). They suggest that Vietnamese manufacturing companies should utilize three most basic and efficient tools for their lean transformation: 5S, Visual Control, and Work Standardization. These tools are applied in Phase of Lean Implementation (Phase 2) and continued in Phase of Maintenance and Improvement (Phase 3) of the roadmap. These 3 tools are believed to support lean activities effectively in order to cut down or remove wastes in operations. These tools can be used with low costs and suitable for all kinds of organization, especially appropriate for small and medium enterprises in Vietnam. Besides, the other tools and methods that respondents consider as necessary ones for Phase 2 and Phase 3 are: VSM, Heijunka, Quick changeover, Lean metrics and monitoring, PDCA, Kanban, and Kaizen. 
Table 4. A proposed roadmap for a successful lean transformation

\begin{tabular}{|c|c|c|}
\hline & HASE 2 & E 3 \\
\hline ARATION & IMPLEMENTATION & \\
\hline $\begin{array}{l}\text { 1. Acknowledge lean in } \\
\text { principle and practice; } \\
\text { identify the meaning of } \\
\text { lean implementation in } \\
\text { current circumstance by } \\
\text { top management and } \\
\text { key positions. } \\
\text { 2. Attain the agreement of } \\
\text { top management for the } \\
\text { urgency of change } \\
\text { through lean } \\
\text { implementation as a } \\
\text { way to realize company } \\
\text { vision, strategies, and } \\
\text { core values. } \\
\text { 3. Build a Lean Project } \\
\text { and Project Team } \\
\text { headed by a top leader } \\
\text { (i.e. CEO) } \\
\text { 4. An implementation plan } \\
\text { is established by Team } \\
\text { Project and approved by } \\
\text { top management with } \\
\text { main issues as follows: } \\
\text { - Status-quo analysis } \\
\text { and evaluation } \\
\text { regarding to key } \\
\text { performance indicators } \\
\text { - Establishment of } \\
\text { strategic approach/ } \\
\text { priority of Project } \\
\text { Objectives } \\
\text { - Estimation } \\
\text { necessary change in } \\
\text { labor force } \\
\text { - Identification } \\
\text { estimated change in andsures relevant } \\
\text { - Master plan } \\
\text { - }\end{array}$ & $\begin{array}{l}\text { Selection and lean implementation of a } \\
\text { prototype area among shop floors } \\
\text { 7. Select an initial scope of project } \\
\text { (prototype area, typical product, } \\
\text { typical manufacturing process) } \\
\text { 8. Define customer values and takt-time } \\
\text { requirements } \\
\text { 9. Review the requirements balanced } \\
\text { between "make" or "buy" } \\
\text { 10.Design and analyze current Value } \\
\text { Stream Map (VSM) } \\
\text { 11.Draft and get approval for future } \\
\text { VSM } \\
\text { 12.Deploy necessary adjustment of shop } \\
\text { floor layout in accordance with lean } \\
\text { principles } \\
\text { 13. Apply suitable lean tools/ methods to } \\
\text { prototype area, such as: } \\
\text { - Identification of } 7 \text { wastes within the } \\
\text { area } \\
\text { - 5S and Visual Management, Andon } \\
\text { - Work standardization } \\
\text { 15. Establish and get approval of lean } \\
\text { expansion to remaining production areas } \\
\text { - TPM (Total Productive Maintenance) } \\
\text { - Poka-yoke } \\
\text { - Quick change-over plans } \\
\text { - Cellular production } \\
\text { - Establishment of pull system and } \\
\text { Kanban tool within the area. } \\
\text { - Application of PDCA circle to } \\
\text { solve problem and improve } \\
\text { continuously } \\
\text { - Establishment and deployment of } \\
\text { information system, report system, } \\
\text { mide lean implementation } \\
\text { - }\end{array}$ & 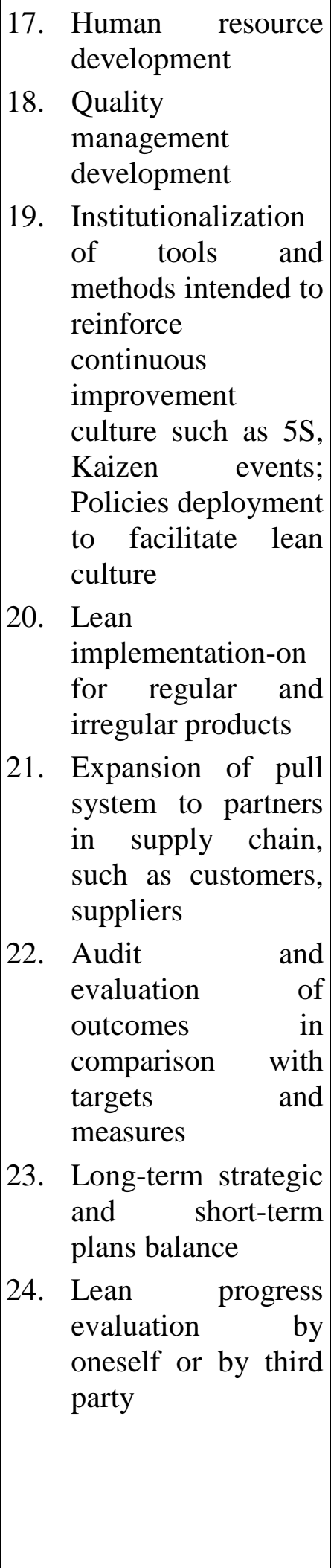 \\
\hline
\end{tabular}




\begin{tabular}{|c|c|c|}
\hline PHASE 1 & PHASE 2 & PHASE 3 \\
\hline PREPARATION & IMPLEMENTATION & $\begin{array}{l}\text { MAINTENANCE \& } \\
\text { IMPROVEMENT }\end{array}$ \\
\hline $\begin{array}{l}\text { 5. In-depth lean training } \\
\text { for key members } \\
\text { (sensei) } \\
\text { 6. Basic lean training for } \\
\text { all workers }\end{array}$ & $\begin{array}{l}\text { 16. Apply lean principles to such other } \\
\text { functions as planning, marketing, } \\
\text { supplying,... with main activities } \\
\text { like : } \\
\text { - Selection and implementation of } \\
\text { suitable lean tools for supportive } \\
\text { units to production } \\
\text { - Selection of suitable production } \\
\text { scheduling in accordance with } \\
\text { "pull" principle } \\
\text { - Inventory management } \\
\text { - Lot size optimization } \\
\text { - Production leveling } \\
\text { - Supply planning in accordance with } \\
\text { lean principle } \\
\text { - Reduction of work-in-process } \\
\text { - Resources adjustment to facilitate } \\
\text { lean implementation }\end{array}$ & \\
\hline
\end{tabular}

5. Discussions on managerial implications

As above results, Vietnamese manufacturing companies can achieve successful lean transformations if they follow the lean roadmap with 24 steps grouped in 3 phases. During phases of the lean roadmap, Vietnamese manufacturing firms consider 10 success factors of lean transformation in order to make sure that their lean approach is appropriate. In phase 1, together with conducting 6 steps of lean preparation (shown in Table 4), Vietnamese companies should check if these factors are examined carefully and well-done: (1) Role of top management in Lean transformation, (2) Involvement and commitment of top management to change, (3) Corporate having its vision, values, code of conducts, standards that are stated clearly and comprehensively, (4) Corporate having culture that facilitates the abilities and readiness of individuals and the whole organization in change implementation, (5)
Transformation is initiated by a change project to new management model (such as Lean project, 5S...), and (6) Corporate having reasonable and persuasive situation for change. If all these 6 factors are done carefully and appropriately, Vietnamese companies can move to Phase 2 (from step 7 to step 16), and then move to Phase 3 (from step 17 to step 24). In Phase 2, Vietnamese companies should have: (1) Application of balanced scorecard, (2) Application of Performance Management (such as KPI...), (3) Assistance of external experts or lean consultants, and (4) Stakeholder communication. Besides, they should have a checklist of lean tools that is suitable for their business context. The most suggested tools for lean transformation are 5S, Visual Control, and Work Standardization. Besides, Vietnamese manufacturing companies can also consider other tools and methods for their use such as: VSM, Heijunka, Quick change- 
over, Lean metrics and monitoring, PDCA, Kanban, and Kaizen. In Phase 3, Vietnamese manufacturing companies should make sure that these factors, tools and methods are continually controlled and used in long term since lean implementation cannot show clear successes in short-term.

For more practically managerial implication, a comparison of problems occurring during the phases of lean roadmap in the two studied companies is shown in Table 5. Besides, the table provides the solutions (at the level of strategic management and the level of operational management) given by the two companies. The lean tools used by the companies are also shown in the table.

Table 5. Comparative problems and solutions of the two companies

\begin{tabular}{|c|c|c|}
\hline & Company A & Company B \\
\hline Problems & $\begin{array}{l}\text { - Back sliding to the old ways of } \\
\text { working } \\
\text { - Uneven knowledge about lean } \\
\text { principles and practices among } \\
\text { workers and supervisors because of } \\
\text { unstable workforce } \\
\text { - Inefficient reporting system } \\
\text { - Low compliance with standards } \\
\text { - Lack of lean expertise } \\
\text { - Do not sustain used lean tools }\end{array}$ & $\begin{array}{l}\text { - Lack of a crisis to create a sense of } \\
\text { urgency } \\
\text { - A traditional cost accounting system } \\
\text { does not recognize the financial value } \\
\text { of shop-floor improvements } \\
\text { - Lack of expertise in controlling and } \\
\text { maintaining activities for lean } \\
\text { transformation } \\
\text { - Not enough training for employees } \\
\text { - Lack of lean expertise }\end{array}$ \\
\hline Solutions & $\begin{array}{l}\text { At the level of strategic management } \\
\text { - Have strong commitment from whole- } \\
\text { hearted top leaders. } \\
\text { - Use of lean expertise from lean } \\
\text { consultants. } \\
\text { - Apply balanced scorecard to facilitate } \\
\text { monitoring system and maintain lean } \\
\text { activities. } \\
\text { - Have good plans with SMART } \\
\text { objectives, in which SMART means } \\
\text { Specific, Measurable, Attainable, } \\
\text { Realistic, and Time-bound. } \\
\text { - Integrate the lean management with } \\
\text { other management systems, such as } \\
\text { ISO 9001, ISO 14001 and so on. } \\
\text { At the level of operational management } \\
\text { - Have a dedicated lean team with clear } \\
\text { roles and responsibilities, and planned } \\
\text { activities. }\end{array}$ & $\begin{array}{l}\text { At the level of strategic management } \\
\text { - Have strong commitment from whole- } \\
\text { hearted top leaders. } \\
\text { - Use of lean expertise from lean } \\
\text { consultants. } \\
\text { - Have clear mission, vision, strategy } \\
\text { communicated repeatedly throughout } \\
\text { the company by proper manners. } \\
\text { - Integrate the lean management with } \\
\text { other management systems, such as } \\
\text { ISO } 9001 \text {, ISO } 14001 \text { and so on. } \\
\text { - Take more investment in training } \\
\text { (lean retraining for each } 3 \text { months for } \\
\text { old an new workers). }\end{array}$ \\
\hline
\end{tabular}




\begin{tabular}{|c|c|c|}
\hline & Company A & Company B \\
\hline & $\begin{array}{l}\text { - Reinforce the monitoring system with } \\
\text { clear and adequate measures. } \\
\text { - Have human resource policy } \\
\text { deployment to motivate employees, } \\
\text { such as awarding policy, appraisal } \\
\text { system accompanied with lean KPIs, } \\
\text { and so on. } \\
\text { - Reinforce measurement-based, fact- } \\
\text { based management style for managers } \\
\text { at all levels. } \\
\text { - Have a consistent maintenance of lean } \\
\text { tools, methods, and activities. }\end{array}$ & $\begin{array}{l}\text { - Take more investment in initiatives } \\
\text { and innovation relating to lean practice } \\
\text { - Have human resource policy } \\
\text { deployment to motivate employees, } \\
\text { such as awarding policy, appraisal } \\
\text { system accompanied with lean KPIs, } \\
\text { and so on. } \\
\text { - Have a consistent maintenance of lean } \\
\text { tools, methods, and activities. }\end{array}$ \\
\hline Lean tools & $\begin{array}{l}\text { 5S, Kaizen, Poka-yoke, Work } \\
\text { Standardization, Multi-task worker, } \\
\text { Kanban, Visual control, VSM, TPM, } \\
\text { Andon, Quick change-over }\end{array}$ & $\begin{array}{l}\text { 5S, Kaizen, Poka-yoke, Work } \\
\text { Standardization, Multi-task worker, } \\
\text { Heijunka, Visual control, VSM, TPM, } \\
\text { Andon, Quick change-over }\end{array}$ \\
\hline
\end{tabular}

As shown in Table 5, although the problems occurring in the two companies are quite different, the commitment of top management is the most important factor for successful lean transformations. Besides, at the level of strategic management, the managers of Vietnamese companies should apply other solutions (such as utilizing lean expertise from lean consultants, applying the balanced scorecard to facilitate monitoring system and maintain lean activities, having good plans with SMART objectives, integrating the lean management with other management systems, such as ISO 9001, ISO 14001 and having clear mission, vision, strategy communicated repeatedly throughout the company by proper manners) to achieve the successful lean transformations. At the level of executive management, managers of Vietnamese firms should consider all the solutions of both companies A and B to have good performances in operations. In overall, the Lean tools used by the two companies are quite similar. Managers of Vietnamese companies can apply these useful tools for their lean transformation during steps of the proposed lean roadmap.

\section{Conclusion and Solutions Conclusion}

The study verifies 32 success factors of lean transformation extracted from literature reviews, and finds out 10 factors that are the most significant and important to help Vietnamese manufacturing companies to achieve successes in lean transformation. Besides, the study proposes a roadmap with 3 phases embracing 24 steps for Vietnamese manufacturing companies to follow a lean transformation. 5S, Visual Control, and Work Standardization are the three most remarkable tools for lean transformation in Vietnamese manufacturing companies, especially in SMEs where costs of lean tool application is a big deal. The study also provides some solutions for Vietnamese companies to get over the difficulties in lean transformation.

Limits of the study can be recognized (such as: the sample is quite small, the studied companies are the producers of carton packaging and printing products) so that it is not really suitable for generating the results 
for all Vietnamese manufacturing companies. However, Lean is a philosophy rather than a method, thus Vietnamese firms can also learn good lessons of lean success from the two cases in this study. Further researches are recommended to enlarge the sample size for the same topic to have more generated results. Further researches can also focus on the importance and the possible utility of each lean tool and method at each step of the proposed lean roadmap.

\section{Solutions}

For difficulties during the phases of lean roadmap, the managers and lean experts have some advices for Vietnamese companies to overcome. At the level of strategic management, Vietnamese companies should: (a) Have strong commitment from wholehearted top leaders, (b) Use of lean expertise from lean consultants, (c) Have clear mission, vision, strategy communicated repeatedly throughout the company by proper manners, (d) Apply balanced scorecard to facilitate monitoring system and maintain lean activities, (e) have good plans with SMART objectives, in which SMART means Specific, Measurable, Attainable, Realistic, and Time-bound, and (f) integration between lean management and other management systems, such as ISO 9001, ISO 14001 and so on. At the level of executive management, Vietnamese companies should: (a) have a dedicated lean team with clear roles and responsibilities, and planned activities, (b) take more investment in training (lean retraining for each 3 months for old an new workers), (c) take more investment in initiatives and innovation relating to lean practice, (d) reinforce the monitoring system with clear and adequate measures, (e) have human resource policy deployment to motivate employees, such as awarding policy, appraisal system accompanied with lean KPIs, and so on, (f) reinforce measurement-based, factbased management style for managers at all levels, and (g) have a consistent maintenance of lean tools, methods, and activities.

Acknowledgement: This study would like to thank Mr. Nguyen Huu Loc who already joined the project and supported to collect data for the study.

\section{REFERENCES}

Alsbridge, A. (2013). Framework for Change Management. Available on: http://www.alsbridge.com, retrieved on [03-12-2014]

Anvari, A., et al. (2011). A proposed dynamic model for a lean roadmap. African Journal of Business Management, 5 (16), 6727-6737.

Bortolotti, T. \& Romano, P. (2012). Lean first, then automate: a framework for process improvement in pure service companies: a case study. Production Planning \& Control: The Management of Operations, 23 (7), 513-522.

FBNC Vietnam, (2013). Chỉ khoảng 2\% doanh nghiệp áp dụng Lean thành công, Available on: http://www.youtube.com/watch?v=QRrwoiBNUqk, retrieved on [01-07-2013]

Jagoda, K., Lonseth, R., \& Lonseth, A. (2013). A bottom-up approach for productivity measurement and improvement. International Journal of Productivity and Performance Management, 62 (4), 387-406. 
Karim, A., \& Arif-Uz-Zaman, K. (2013). A methodology for effective implementation of lean strategies and its performance evaluation in manufacturing organizations. Business Process Management Journal, 19 (1), 169-196.

Liker, J. (2004). The Toyota Way: 14 Management Principles from the World's Greatest Manufacturer, McGraw-Hill.

Nguyen, T. D. N. \& Bui, N. H. (2010). Lean implementation in Vietnam through some cases. Journal of Development \& Integration, 8, 41-48.

Perrett, P. (2011). Leadership in a Globalized World. Lecture of EMBA-MCI.

Ransom, C. A. (2007). Wall Street view of Lean transformation. Lean Enterprise Institute, available at: www.lean.org/events/dec_18_webinar_downloadable_transcript.pdf.

Reinders, B. (2010). Case Study: BC Hydro's Enterprise Change Management Framework From the Ground Up. Available on: www.acmp.info/conference/files/reinders-2010.pdf, retrieved on: [03-12-2014]

Rose, A.M.N., et al. (2010). Development of framework for lean manufacturing implementation in SMEs. Proceedings of the 11th Asia Pacific Industrial Engineering and Management Systems Conference and the 14th Asia Pacific Regional Meeting of International Foundation for Production Research; Malacca, Malaysia. Available on: http://www.apiems.net/archive/apiems2010/pdf/SE/389.pdf.

Simoes, V. (2008). Critical Factors of Lean Implementation in Manufacturing Environments. Available on: http://repositorio-aberto.up.pt/bitstream/10216/59573/2/Texto\%20integral.pdf, retrieved on [30-04-2015]

Suhartini, M.J., Rizauddin, R., \& Nizam, A.R. (2012). Applying lean principles, tools and techniques in set parts supply implementation. World Academy of Science, Engineering and Technology, 72, 519-523.

Van-Aken, E.M., Farris, J.A., Glover, W.J., \& Letens, G., (2010). A framework for designing, managing, and improving Kaizen event programs. International Journal of Productivity and Performance Management, 59 (7), 641-667.

Vinodh, S., Gautham, S.G., \& Ramiya, A. (2011). Implementing lean sigma framework in an Indian automotive valves manufacturing organisation: a case study. Production Planning \& Control: The Management of Operations, 22 (7), 708-722.

Wooley, K. (2008). The key to a successful lean journey? Leadership! Industry Week, available on: www.industryweek.com/articles, retrieved on [24-04-2013] 